medRxiv preprint doi: https://doi.org/10.1101/2020.04.27.20081984; this version posted May 3, 2020. The copyright holder for this preprint

(which was not certified by peer review) is the author/funder, who has granted medRxiv a license to display the preprint in perpetuity.

It is made available under a CC-BY-NC 4.0 International license .

\title{
DISTINGUISHING L AND H PHENOTYPES OF COVID-19 USING A SINGLE X-RAY IMAGE
}

\author{
Mohammad Tariqul Islam and Jason W. Fleischer \\ Princeton University
}

\begin{abstract}
Recent observations have shown that there are two types of COVID-19 response: an H phenotype with high lung elastance and weight, and an L phenotype with low measures ${ }^{1}$. H-type patients have pneumonia-like thickening of the lungs and require ventilation to survive; L-type patients have clearer lungs that may be injured by mechanical assistance ${ }^{2,3}$. As treatment protocols differ between the two types, and the number of ventilators is limited, it is vital to classify patients appropriately. To date, the only way to confirm phenotypes is through high-resolution computed tomography ${ }^{2}$. Here, we identify $\mathrm{L}$ - and $\mathrm{H}$-type patients from their frontal chest $\mathrm{x}$-rays using feature-embedded machine learning. We then apply the categorization to multiple images from the same patient, extending it to detect and monitor disease progression and recovery. The results give an immediate criterion for coronavirus triage and provide a methodology for respiratory diseases beyond COVID- 19 .
\end{abstract}

It is commonly thought that COVID-19 presents as other coronavirus diseases, with Acute Respiratory Distress Syndrome (ARDS) caused by pneumonia-like thickening of the lungs ${ }^{4}$. However, recent observations suggest that half of all patients present differently, with near-normal breathing mechanics, clearer lungs, and hypoxia caused by poor oxygen transfer to the capillaries ${ }^{1,2,5}$. The ARDS-like $\mathrm{H}$ phenotype is characterized by high lung elastance, high weight, and high recruitment ${ }^{2}$ (potential to reexpand collapsed lung tissue, e.g. closed alveoli ${ }^{6}$ ); these patients require mechanical ventilation to survive ${ }^{7}$. The corresponding measures for the L phenotype are $\mathrm{low}^{2}$; applying high-pressure ventilation in these cases can injure lungs and precipitate a rapid worsening to $\mathrm{ARDS}^{3,5}$. It is vital to classify patients appropriately.

To date, the only way to confirm the phenotypes is through high-resolution computed tomography (CT, Fig. 1$)^{2}$. This is inhibitory for rapid triage and impossible for hospitals with limited resources. Here, we introduce a machine-learned early detection system to identify COVID-19 and differentiate its L and H phenotypes using conventional chest x-rays.

That this is possible comes from the origin of CT images: they are made from a collection of x-rays taken at different angles, each of which contains information on lung size, shape, and density. Resolution of CT images improves with the number of different views; higher resolution removes artifacts and provides cross-sections that allow visual separation of internal organs (Figs. 1a-c). The significance of this can be seen by comparing CT scans with individual x-ray images (Figs. 1e-h): each x-ray picture is a 2D projection of the 3D body image, so that all internal features are superimposed. This overlap complicates diagnosis considerably, especially when disease forms around the heart and behind the breastbone. Nevertheless, frontal x-rays are the most frequent radiological test performed in intensive care units ${ }^{8}$ and are used often at the initial point of care to diagnose respiratory distress, e.g. pneumonia and chronic obstructive pulmonary disease ${ }^{9}$. 
medRxiv preprint doi: https://doi.org/10.1101/2020.04.27.20081984; this version posted May 3, 2020. The copyright holder for this preprint (which was not certified by peer review) is the author/funder, who has granted medRxiv a license to display the preprint in perpetuity. It is made available under a CC-BY-NC 4.0 International license .

The images in Figs. 1d-h, taken from the publicly available COVIDx dataset ${ }^{10}$, show representative chest $\mathrm{x}$-rays from normal, pneumonia-positive ${ }^{11}$, and COVID-19-positive patients ${ }^{12}$. Compared with a normal image, a pneumonia x-ray shows a diffuse pattern characteristic of fluid-filled lungs. Known as ground-glass opacities when translucent and consolidation when fully opaque, these regions form when an overstimulated immune system fills the alveoli with cells and fluid ${ }^{13,14}$. Consequently, the location and density of these regions give many indications of the type and stage of disease. Similar patterns are seen in COVID-19 patients $^{15}$, particularly as the illness progresses (Figs. 1b,d,f).

Figure 2 shows the results of three different numerical approaches for embedding features from the $\mathrm{x}$ ray images. Each reduces the high-dimensional image space to a $2 \mathrm{D}$ plot of the samples. All are unsupervised, in the sense that data labels are known but only provided afterward for visualization; they are not seen or used by the algorithms. Figure 2a shows the output from Principal Component Analysis (PCA), which is a linear technique that rearranges the input data to maximize variance. It preserves large distances between points, so that samples that are distinct from each other end up far apart. It gives three clusters of $\mathrm{x}$-rays with significant overlap among the points. Projection along the main principal component (Fig. 2b) gives a Gaussian profile for COVID-19 patients, a direct result of the broad statistics of the underlying data.

In contrast, Stochastic Neighbor Embedding (SNE) is a nonlinear mapping that emphasizes similarity between sample points, e.g. the joint probability of having features in common ${ }^{16}$. Figures $2 \mathrm{c}, \mathrm{d}$ show the results of SNE using Student's t-test as a metric (Gaussian distributions for relative probability) ${ }^{17}$. Remarkably, the network organizes the COVID-19 patients into two distinct clusters: one that resembles pneumonia and one that has a more normal presentation.

Unfortunately, the COVID image dataset ${ }^{12}$ has no labels for the $\mathrm{L}$ and $\mathrm{H}$ phenotypes. However, most chest $\mathrm{X}$-rays have radiologist and physician notes on the stage of disease and response to treatment. This metadata, discussed below and in the Supplementary Information, supports the labeling of t-SNE data according to phenotype.

One problem with t-SNE clustering is that the mapping only gives information on similarity within a group, with no measure of dissimilarity between them. Neither the size of the clusters nor the distance between them has any physical meaning ${ }^{18}$. A more sophisticated clustering algorithm that overcomes these issues is Uniform Manifold Approximation and Projection (UMAP), which categorizes objects using Riemannian geometry and algebraic topology ${ }^{19}$. It is a $k$-neighbor graph-based algorithm in the same class as t-SNE and again gives two clusters (Figs. 2e,f). Compared with the t-SNE plot, the UMAP plot has tighter groupings and sharper boundaries between the x-ray types. As a consistency check, we use the L and $\mathrm{H}$ labels from the t-SNE clusters to color the UMAP (again, this is for visualization purposes only and 
medRxiv preprint doi: https://doi.org/10.1101/2020.04.27.20081984; this version posted May 3, 2020. The copyright holder for this preprint (which was not certified by peer review) is the author/funder, who has granted medRxiv a license to display the preprint in perpetuity. It is made available under a CC-BY-NC 4.0 International license .

was not used by the algorithm). This confirms that UMAP separates the same points as t-SNE, but with a better mapping.

A provocative feature of both mappings is the isolation of the $\mathrm{H}$ phenotype from the pneumonia samples, indicating a unique signature of COVID-19 infection. Similarly, the placement of L-type patients between the reference ones indicates identifiable lung damage in the $\mathrm{x}$-ray image, reconciling the simultaneous observations of normal breathing and low oxygenation levels ${ }^{1,5}$. Future work will look for signs of susceptibility to ventilation-induced lung injury ${ }^{3,20}$ (a diagnostic not currently available ${ }^{20}$ ) and test the hypothesis that COVID-19 is a different class of coronavirus from those that cause MERS and SARS ${ }^{21}$.

As UMAP gives quantitative distance metrics, and accommodates new data better than t-SNE ${ }^{19}$, we focus analysis on the UMAP mapping. As a first step, we observe that the groupings in Fig. 2e are nearly orthogonal; re-plotting the data in terms of these major axes gives the representation in Fig. 3a. The two clusters of data are bound by distinct ellipses, each containing $95 \%$ of their identified x-rays. The vertical $\mathrm{L}$ cluster is broader and more disperse than the horizontal $\mathrm{H}$ cluster, with external points on both sides of its major axis. From the patient metadata ${ }^{10}$, it was found that the isolated point in the upper left is from the youngest patient in the dataset. The outlying point in the upper right has a partner $\mathrm{x}$-ray image inside the $\mathrm{L}$ ellipse, taken from the same patient at an earlier time. The "misclassified" point in the H cluster also has an earlier partner inside the L ellipse. The remaining external point, bisecting the ellipses, has ambiguous radiology and no clear marker suggesting outlier status.

The algorithms treat each x-ray independently and have no knowledge that multiple images could belong to the same patient. When clustering images within a set, the two methods have different priorities: t-SNE emphasizes commonality, while UMAP takes into account both locally similar features and globally different ones. This difference explains the appearance of an " $L$ " point in the H cluster and, combined with a distance metric, suggests that UMAP can provide a scale of disease severity. While the limited data prevents its development here, patient progression and recovery are captured: worsening condition appears as movement from left to right in parameter space (normal- to pneumonia-like), while improvement goes in the opposite direction. Significantly, this ordering is preserved when UMAP is applied to new test data as well. Details are given in the Supplementary Information.

A down side of this and all machine learning techniques is that it is not clear what the machine is learning. Here, it could be the presence and density of opacities ${ }^{14}$, different rib thickness ${ }^{22,23}$ or heart size (from inflammation or strain ${ }^{24}$ ), or some other as-yet-unknown marker. In Figs. 3b-d, we label the points according to the confounding factors of gender, age, and stage of infection (measured in days from first hospitalization or sign of illness). The corresponding histograms are shown in Fig. 4. There are more males than females identified in the COVID-19 data, but they are dispersed in equal measure throughout the clusters (Figs. 3b, 4a,b). Labeled H-type patients are on average 20 years older than L-type patients (Figs. 
3c, 4c,d), but their x-rays were taken at similar stages of development (Figs. 3d, 4e,f). Interestingly, both groups were intubated at the same rate (Figs. 4g,h), but the survival rate of L-type patients is higher (Figs. $4 \mathrm{i}, \mathrm{j})$. These distributions are consistent with observations of disease severity ${ }^{25}$ and re-affirm the distinct epidemiology of COVID-19 from other viral pandemics, such as the $1918 \mathrm{flu}^{26}$.

With the current data, it would be beneficial to repeat the training for more specific regions of interest and to use a wider range of metrics, e.g. structural similarity ${ }^{27}$ and image statistics ${ }^{28}$. Likewise, it would help to leverage an additional viewpoint, such as the lateral (side) x-ray images commonly taken at the same time as the frontal view. Lateral x-rays are particularly useful for assessing the air spaces behind the breastbone and heart ${ }^{13}$ and provide an extreme form of limited-angle tomography ${ }^{29}$, giving much-needed perspective for volume estimation. Finally, it is important to correlate the x-ray images with data from other observations as well ${ }^{30}$, such as cardiovascular ${ }^{24}$ and renal ${ }^{31}$ metrics, the improvement of many patients via prone positioning (laying on the stomach) ${ }^{32}$, and acoustic signatures of wheezing, gasping, and coughing ${ }^{33}$. Far more data and clinical studies are needed, but the classification of patients should start now. 
medRxiv preprint doi: https://doi.org/10.1101/2020.04.27.20081984; this version posted May 3, 2020. The copyright holder for this preprint (which was not certified by peer review) is the author/funder, who has granted medRxiv a license to display the preprint in perpetuity. It is made available under a CC-BY-NC 4.0 International license .

\section{METHODS}

We used the publicly available COVIDx dataset ${ }^{10}$, which is a combination of COVID-19 image data collection $^{12}$ and the RSNA pneumonia dataset ${ }^{11}$. To date, the training set includes posteroanterior (PA) $\mathrm{x}$ ray images from 7966 pneumonia-positive patients and 8066 "normal" patients (pneumonia-negative and COVID-19-negative patients) but only 98 images of COVID-19-positive patients. The test set consists of 100 normal, 100 pneumonia, and 10 COVID-19 patients. For the t-SNE and UMAP analysis, we employed 308 normal, 308 pneumonia, and 98 COVID-19 x-ray images.

\section{$\underline{\text { Transformation and Preprocessing }}$}

Images are resized such that the lowest dimension contains 256 pixels and then center-cropped for feature analysis. For fine-tuning the network, we augmented the data with random jitter in brightness, random crops, and horizontal and vertical flips.

\section{Neural Network}

We use a DenseNet-121 architecture $^{34}$ trained on the ImageNet database ${ }^{35}$, performed using the PyTorch deep learning library ${ }^{36}$. The network uses Adam optimization ${ }^{37}$ with an initial learning rate of 0.0001 . It is then trained for a total of 10 epochs, with the learning rate decreasing by a factor of 0.1 every 3 epochs. For evaluation, we employ a five-crop criterion in which we take four corner crops and one center crop of the image and make decisions based on majority rule. The fine-tuned network showed a sensitivity of $80 \%$ for COVID-19 detection and $93 \%$ for pneumonia detection.

\section{Clustering Algorithms}

Image features output from the pre-trained network are grouped using the $\mathrm{t}-\mathrm{SNE}^{17}$ and $\mathrm{UMAP}^{19}$ clustering algorithms. To confirm consistency, the t-SNE perplexity value was varied from 20 to 100 and the number of iterations was varied from 1000 to 5000; for the final results, the perplexity value is set to 50 and the number of iterations is set to 1000. For the UMAP analysis, spread values of 1-3 were considered; for the final results, the value is set to 2 . To obtain a consistent topology, the UMAP distance parameter is tuned to 0.1 .

\section{CONFLICTS OF INTEREST}

The authors have no conflict of interest relevant to this article.

\section{ACKNOWLEDGEMENTS}

The authors thank DARPA and the AFOSR for general support. 
medRxiv preprint doi: https://doi.org/10.1101/2020.04.27.20081984; this version posted May 3, 2020. The copyright holder for this preprint (which was not certified by peer review) is the author/funder, who has granted medRxiv a license to display the preprint in perpetuity.

It is made available under a CC-BY-NC 4.0 International license .
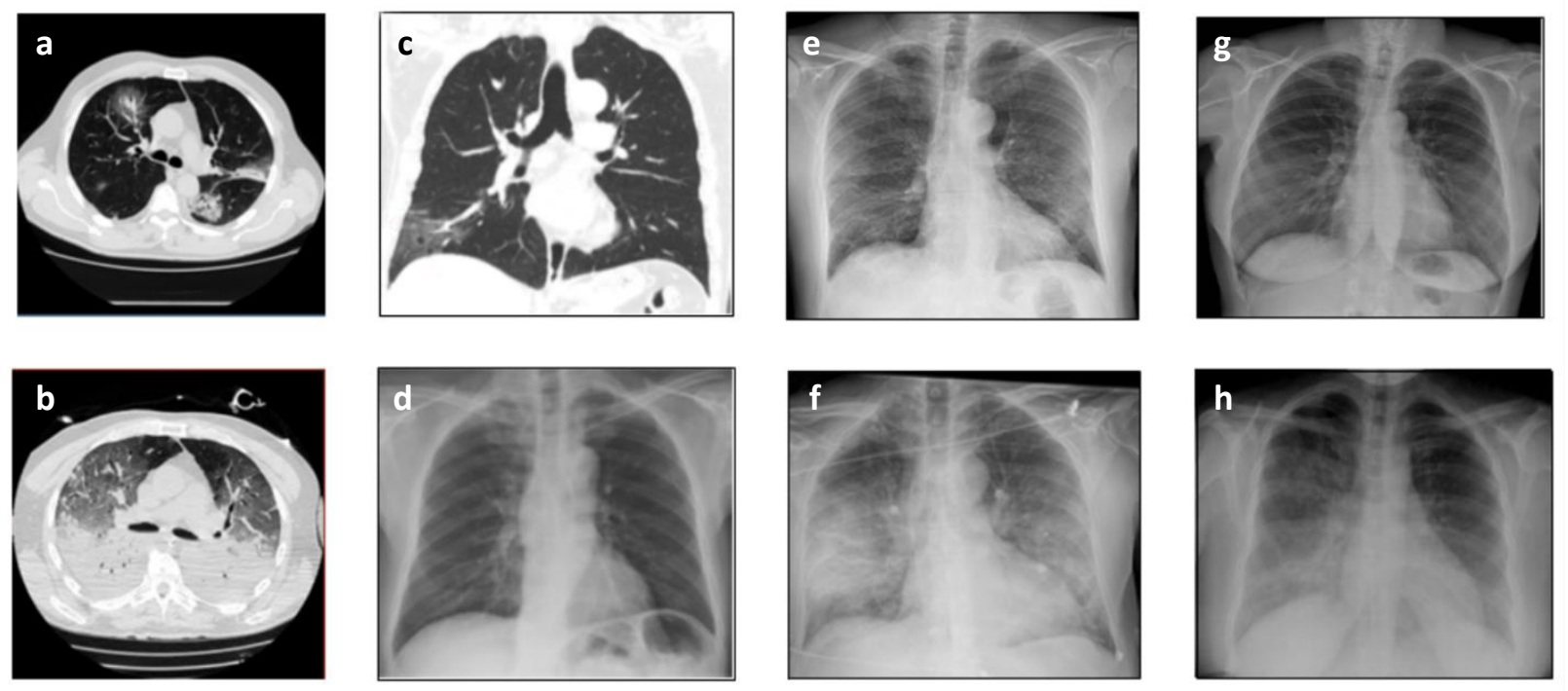

Figure 1. Computed tomography and $x$-ray data. (a,b) High-resolution CT of COVID-19 patient at (a) admission to the hospital (b) 7 days later. (c,d) Posteroanterior CT (c) and x-ray (d) images of COVID-19 patient on same day. (e,f) x-ray data of a COVID-19 patient at (e) admission, (f) 2 days later. (g) Normal $\mathrm{x}$-ray. (g) x-ray of patient with viral pneumonia. $(\mathrm{a}, \mathrm{b})$ taken from [2]. $(\mathrm{c}, \mathrm{d})$ taken from [15] $(\mathrm{e}-\mathrm{h})$ taken from [12]. 

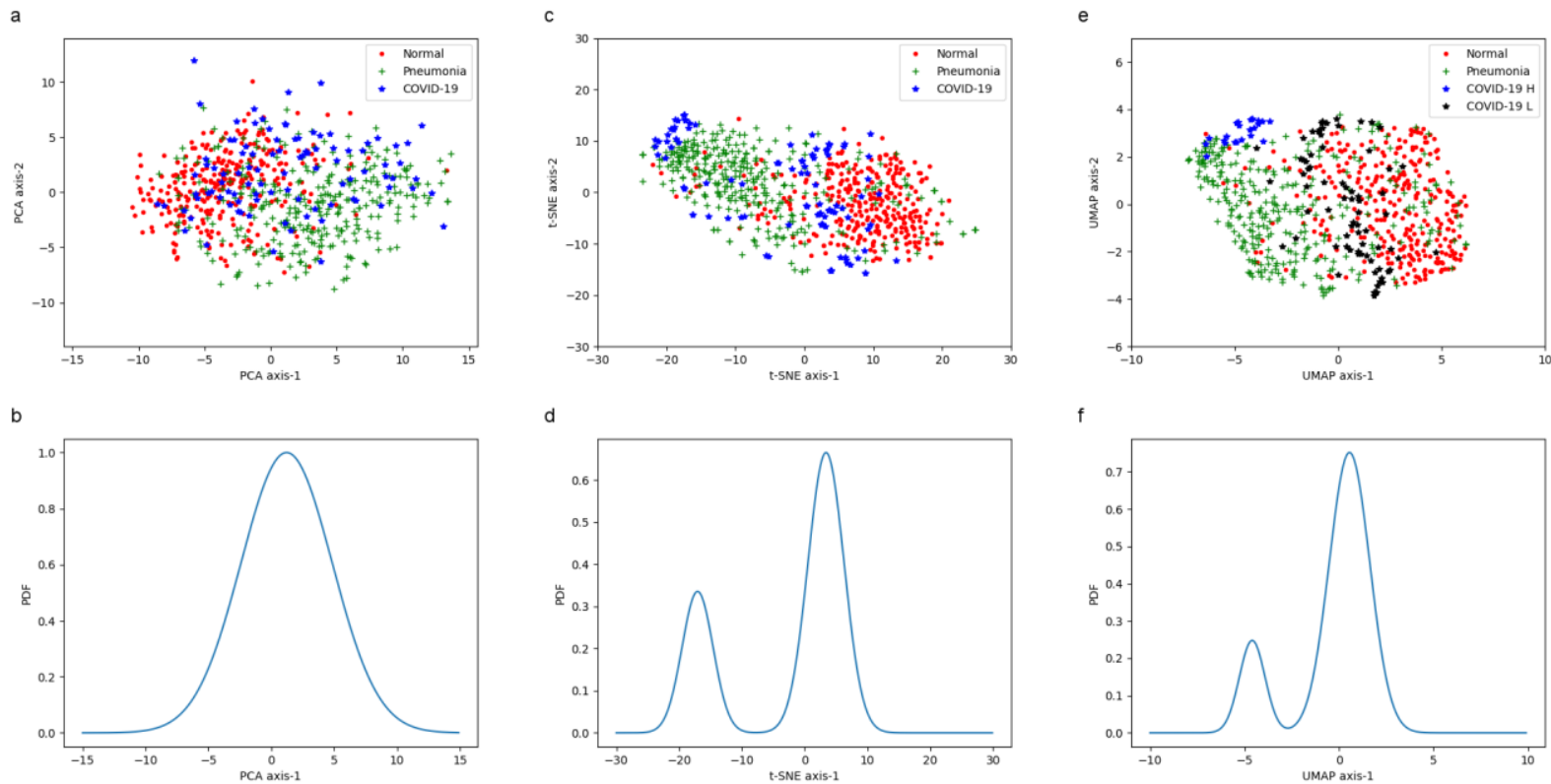

Figure 2. Clustering of COVID-19 patients from frontal (PA) x-ray images. Top row: Scatter plots of different algorithms. Each sample point is an x-ray image and was labeled for visualization only; labels were not used for training. Bottom row: projections. (a,b) Principal Component Analysis. (c-f) Featureembedded machine learning. (c,d) t-SNE, (e,f) UMAP. 
medRxiv preprint doi: https://doi.org/10.1101/2020.04.27.20081984; this version posted May 3, 2020. The copyright holder for this preprint (which was not certified by peer review) is the author/funder, who has granted medRxiv a license to display the preprint in perpetuity.

It is made available under a CC-BY-NC 4.0 International license .

a

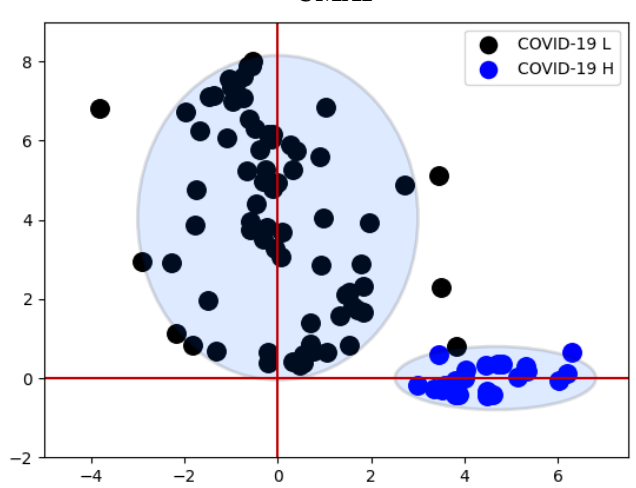

b

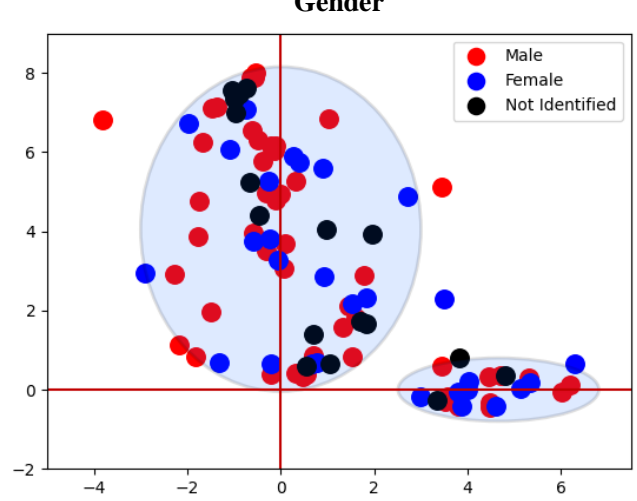

c

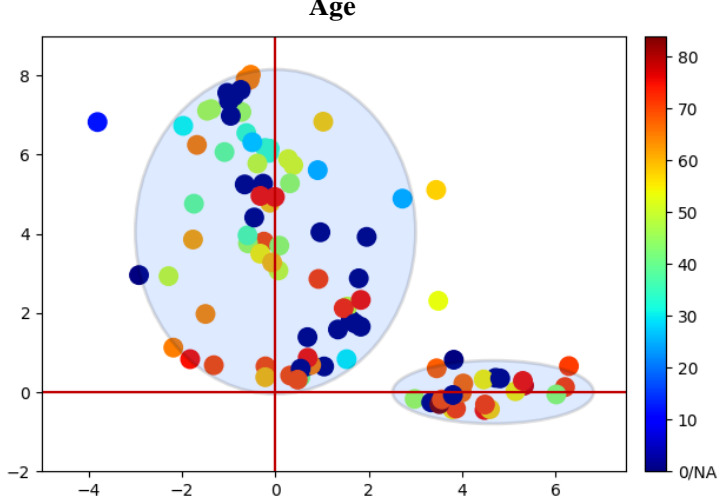

d

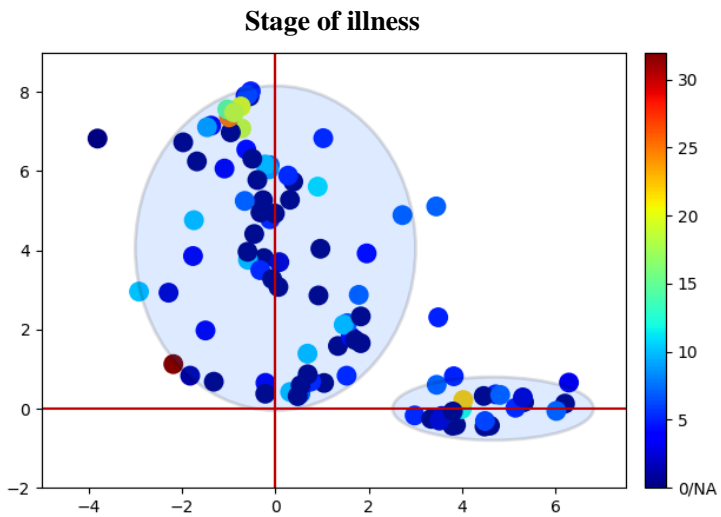

Figure 3. Classification of $L$ and $H$ phenotypes using UMAP clusters. (a) Re-mapped plot of Fig. 2e using principal axes. (b) Gender. (c) Age. (d) Stage of illness (measured in days from first hospitalization or sign of infection). Ellipse boundaries indicate $95 \%$ confidence levels. 
medRxiv preprint doi: https://doi.org/10.1101/2020.04.27.20081984; this version posted May 3, 2020. The copyright holder for this preprint (which was not certified by peer review) is the author/funder, who has granted medRxiv a license to display the preprint in perpetuity.

It is made available under a CC-BY-NC 4.0 International license .
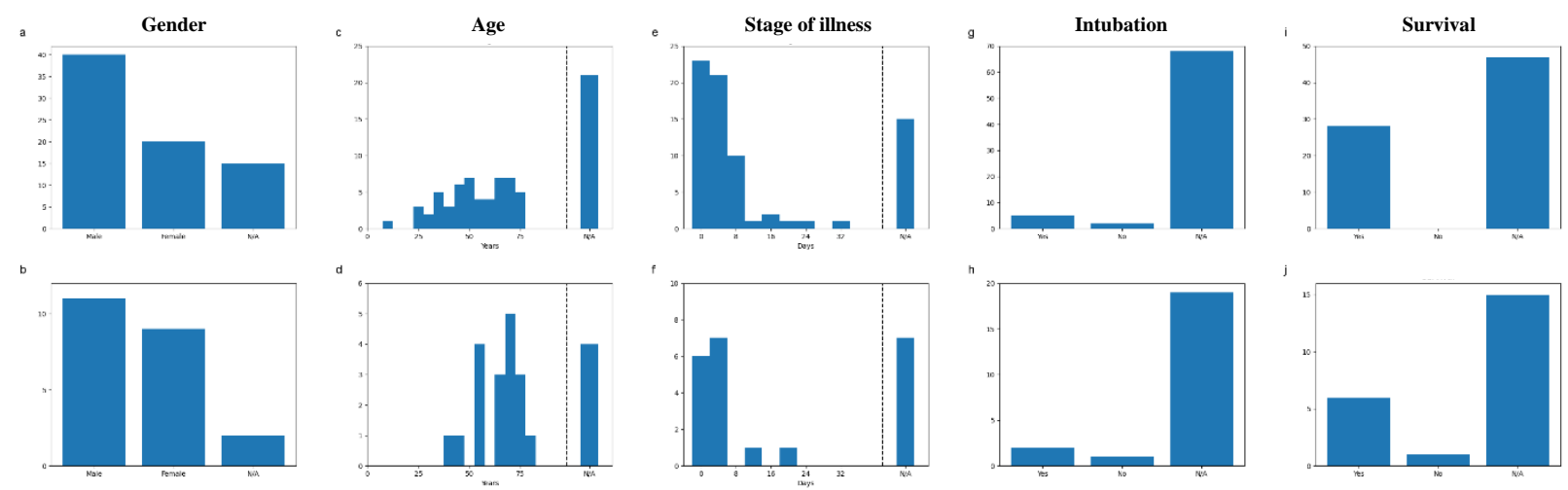

Figure 4. Histograms of confounding factors. Top row: L phenotype. Bottom row: H phenotype. There are more L-type than H-type patients, but their distributions are similar. 
medRxiv preprint doi: https://doi.org/10.1101/2020.04.27.20081984; this version posted May 3, 2020. The copyright holder for this preprint (which was not certified by peer review) is the author/funder, who has granted medRxiv a license to display the preprint in perpetuity. It is made available under a CC-BY-NC 4.0 International license .

\section{REFERENCES}

1 Gattinoni, L. et al. Covid-19 does not lead to "typical" acute respiratory distress syndrome. American Journal of Respiratory and Critical Care Medicine, doi:https://doi.org/10.1164/rccm.202003-0817LE (2020).

2 Gattinoni, L. et al. COVID-19 pneumonia: different respiratory treatments for different phenotypes? Intensive Care Medicine, doi:10.1007/s00134-020-06033-2 (2020).

3 Dreyfuss, D. \& Saumon, G. Ventilator-induced lung injury: lessons from experimental studies. Am J Respir Crit Care Med 157, 294-323, doi:10.1164/ajrccm.157.1.9604014 (1998).

4 Cascella, M., Rajnik, M., Cuomo, A., Dulebohn, S. C. \& Di Napoli, R. Features, Evaluation and Treatment Coronavirus (COVID-19). StatPearls [Internet] (2020).

5 Kyle-Sidell, D. C. in WebMD interview https://blogs.webmd.com/publichealth/20200407/coronavirus-in-context-do-covid-19-vent-protocols-need-a-second-look (2020).

6 Mols, G., Priebe, H. J. \& Guttmann, J. Alveolar recruitment in acute lung injury. BJA: British Journal of Anaesthesia 96, 156-166, doi:10.1093/bja/aei299 (2005).

7 Gattinoni, L. et al. Lung Recruitment in Patients with the Acute Respiratory Distress Syndrome. New England Journal of Medicine 354, 1775-1786, doi:10.1056/NEJMoa052052 (2006).

8 Ganapathy, A., Adhikari, N. K. J., Spiegelman, J. \& Scales, D. C. Routine chest x-rays in intensive care units: a systematic review and meta-analysis. Critical Care 16, R68, doi:10.1186/cc11321 (2012).

9 Cardinale, L., Volpicelli, G., Lamorte, A., Martino, J. \& veltri, A. Revisiting signs, strengths and weaknesses of Standard Chest Radiography in patients of Acute Dyspnea in the Emergency Department. Journal of Thoracic Disease 4, 398-407 (2012).

10 Wang, L. \& Wong, A. COVID-Net: A Tailored Deep Convolutional Neural Network Design for Detection of COVID-19 Cases from Chest Radiography Images. arXiv 2003:09871 (2020).

11 America, R. S. o. N. RSNA pneumonia detection challenge, https://www.kaggle.com/c/rsnapneumonia-detection-challenge/data (2019).

12 Cohen, J. P., Morrison, P. \& Dao, L. Covid-19 Image Data Collection. arxiv 2003.11597 (2020).

13 Lynch, D. A., Newell, J. D. \& Lee, J.-S. Imaging of diffuse lung disease. (B.C. Decker, 2000).

14 Engeler, C. E., Tashjian, J. H., Trenkner, S. W. \& Walsh, J. W. Ground-glass opacity of the lung parenchyma: a guide to analysis with high-resolution CT. American Journal of Roentgenology 160, 249-251, doi:10.2214/ajr.160.2.8424326 (1993).

$15 \mathrm{Ng}, \mathrm{M}$-Y. et al. Imaging Profile of the COVID-19 Infection: Radiologic Findings and Literature Review. Radiology: Cardiothoracic Imaging 2, e200034, doi:10.1148/ryct.2020200034 (2020).

16 Hinton, G. \& Roweis, S. in Proceedings of the 15th International Conference on Neural Information Processing Systems 857-864 (MIT Press, 2002).

17 van der Maaten, L. \& Hinton, G. Visualizing data using t-SNE. Journal of Machine Learning Research 9, 2579-2605 (2008).

18 Wattenberg, M., Viegas, F. \& Johnson, I. How to use t-SNE effectively, https://distill.pub/2016/misread-tsne/ (2016). 
medRxiv preprint doi: https://doi.org/10.1101/2020.04.27.20081984; this version posted May 3, 2020. The copyright holder for this preprint (which was not certified by peer review) is the author/funder, who has granted medRxiv a license to display the preprint in perpetuity. It is made available under a CC-BY-NC 4.0 International license .

19 Mclnnes, L. \& Healy, J. UMAP: Uniform Manifold Approximation and Projection for Dimension Reduction. (2018).

20 Madahar, P. \& Beitler, J. R. Emerging concepts in ventilation-induced lung injury. F1000Res 9, F1000 Faculty Rev-1222, doi:10.12688/f1000research.20576.1 (2020).

21 Petrosillo, N., Viceconte, G., Ergonul, O., Ippolito, G. \& Petersen, E. COVID-19, SARS and MERS: are they closely related? Clinical Microbiology and Infection, doi:https://doi.org/10.1016/j.cmi.2020.03.026 (2020).

22 Uysal Ramadan, S. et al. Sex determination from measurements of the sternum and fourth rib using multislice computed tomography of the chest. Forensic Science International 197, 120.e121120.e125, doi:https://doi.org/10.1016/j.forsciint.2009.12.049 (2010).

23 Weaver, A. A., Schoell, S. L. \& Stitzel, J. D. Morphometric analysis of variation in the ribs with age and sex. J Anat 225, 246-261, doi:10.1111/joa.12203 (2014).

24 Zheng, Y.-Y., Ma, Y.-T., Zhang, J.-Y. \& Xie, X. COVID-19 and the cardiovascular system. Nature Reviews Cardiology, doi:10.1038/s41569-020-0360-5 (2020).

25 Verity, R. et al. Estimates of the severity of coronavirus disease 2019: a model-based analysis. The Lancet Infectious Diseases, doi:10.1016/S1473-3099(20)30243-7 (2020).

26 Barry, J. M. The great influenza : the story of the deadliest plague in history. (Penguin Books, 2005).

27 Wang, Z., Bovik, A. C., Sheikh, H. R. \& Simoncelli, E. P. Image quality assessment: from error visibility to structural similarity. IEEE transactions on image processing 13, 600-612 (2004).

28 Wang, Y., Sun, X. \& Fleischer, J. W. When deep denoising meets iterative phase retrieval. arxiv $2003.01792(2020)$.

29 Pegard, N. C., Toth, M. L., Driscoll, M. \& Fleischer, J. W. Flow-scanning optical tomography. Lab Chip 14, 4447-4450, doi:10.1039/c4lc00701h (2014).

30 Huang, C. et al. Clinical features of patients infected with 2019 novel coronavirus in Wuhan, China. The Lancet 395, 497-506, doi:10.1016/S0140-6736(20)30183-5 (2020).

31 Cheng, Y. et al. Kidney disease is associated with in-hospital death of patients with COVID-19. Kidney International, doi:10.1016/j.kint.2020.03.005.

32 Henderson, W. R., Griesdale, D. E. G., Dominelli, P. \& Ronco, J. J. Does prone positioning improve oxygenation and reduce mortality in patients with acute respiratory distress syndrome? Can Respir J 21, 213-215, doi:10.1155/2014/472136 (2014).

33 Abeyratne, U., Swarnkar, V., Setyati, A. \& Triasih, R. Cough Sound Analysis Can Rapidly Diagnose Childhood Pneumonia. Annals of biomedical engineering 41, doi:10.1007/s10439-013-0836-0 (2013).

34 Huang, G., Liu, Z., Maaten, L. V. D. \& Weinberger, K. Q. in 2017 IEEE Conference on Computer Vision and Pattern Recognition (CVPR). 2261-2269.

35 Russakovsky, O. et al. ImageNet Large Scale Visual Recognition Challenge. International Journal of Computer Vision (IJCV) 115, 211-252 (2015).

36 Paszke, A. et al. in Advances in Neural Information Processing Systems 32 (eds H. Wallach et al.) 8026-8037 (Curran Associates, Inc., 2019).

37 Kingma, D. \& Ba, J. Adam: A Method for Stochastic Optimization. International Conference on Learning Representations (2014). 
medRxiv preprint doi: https://doi.org/10.1101/2020.04.27.20081984; this version posted May 3, 2020. The copyright holder for this preprint (which was not certified by peer review) is the author/funder, who has granted medRxiv a license to display the preprint in perpetuity. It is made available under a CC-BY-NC 4.0 International license .

Supplementary Information for

Distinguishing $L$ and $H$ phenotypes of Covid-19 using a single x-ray image

Mohammad Tariqul Islam and Jason W. Fleischer

Department of Electrical Engineering, Princeton University, Princeton, NJ 08540

\section{This PDF file includes:}

Supplementary Text

Supplementary Figures

Supplementary References 
medRxiv preprint doi: https://doi.org/10.1101/2020.04.27.20081984; this version posted May 3, 2020. The copyright holder for this preprint (which was not certified by peer review) is the author/funder, who has granted medRxiv a license to display the preprint in perpetuity. It is made available under a CC-BY-NC 4.0 International license.

This Supplementary Information analyzes the data in more detail. Part 1 discusses the dimensionreduction methods of $\mathrm{t}-\mathrm{SNE}^{1}$ and $\mathrm{UMAP}^{2}$. Part 2 describes the discovery by UMAP of a mislabeled $\mathrm{x}-$ ray image in the COVIDx dataset ${ }^{3}$. Part 3 provides a deeper discussion of existing points in the UMAP classification and Part 4 explores predictive testing by UMAP for new data points.

\section{1. t-SNE and UMAP algorithms}

Both t-SNE and UMAP reduce the high-dimensional dataset $\mathrm{X}$ to a low-dimensional space $\mathrm{Y}$ (typically, the target space is two-dimensional). In t-SNE, image pairs are assigned a joint probability and grouped by similarity ${ }^{1}$. The algorithm is non-parametric, i.e. it does not learn a mapping $f: X \rightarrow Y$. Consequently ${ }^{1,4}$,

1) there may be no meaning to the placement of clusters;

2) there may be no meaning to the distance between clusters; and

3) the algorithm cannot simply add new data points to an existing plot; it must be re-run on the expanded set when new data points are added.

The first two properties mean that multiple runs of t-SNE may result in multiple output geometries. In our case, we observe two different manifestations, depending on the (random) initial condition chosen to start the algorithm: half the time it places a COVID-19 cluster between those of pneumonia and normal x-rays (Fig. S1a), half the time it places the COVID-19 cluster above the normal one (Fig. S1b). The third property can be overcome by parameterizing t-SNE to accommodate new data ${ }^{5}$.

A more modern algorithm better suited for generalization is $\mathrm{UMAP}^{2}$. This algorithm provides a distance metric between points (typically Riemannian) and gives a more consistent topology over a wide range of parameters and initial conditions (Figs. 1c,d). Accordingly, we use UMAP for analysis and prediction.
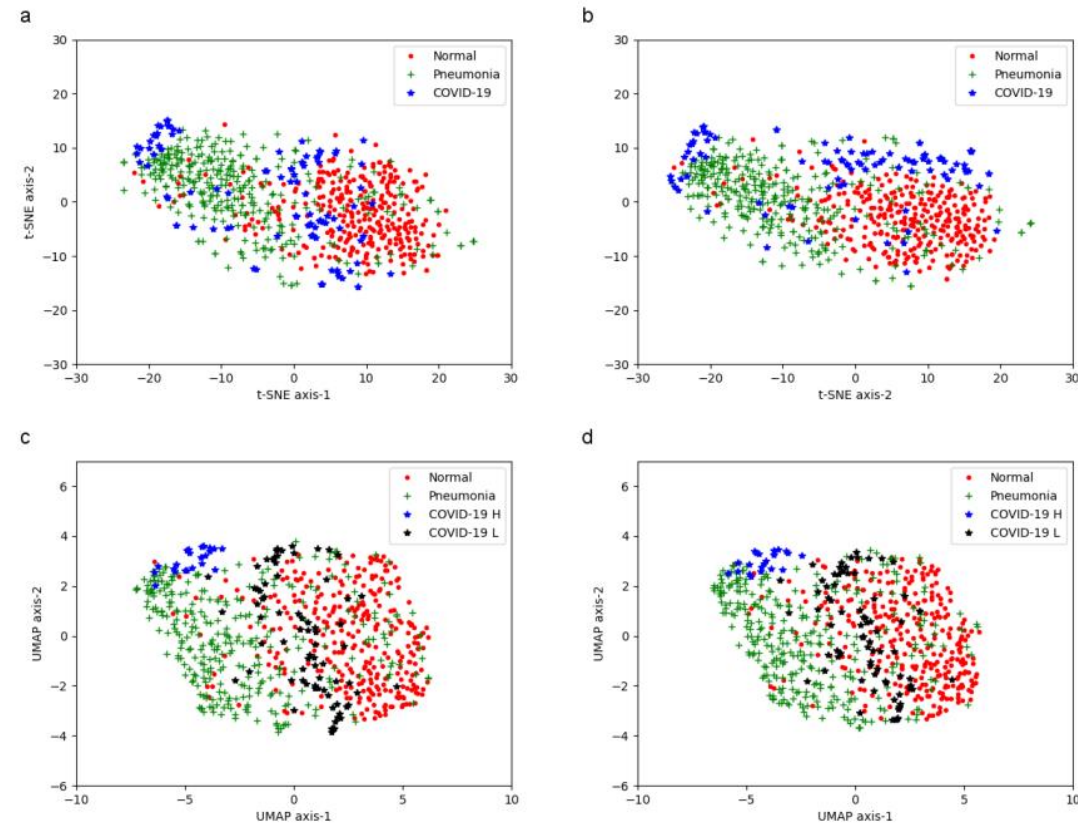

Figure S1. Clustering algorithms. (a,b) t-SNE clustering for two different random initializations. (a) Fig. 2c from the main text. (b) Second configuration. (c,d) UMAP for two different random initializations. In all cases, the UMAP topology remained the same. 
2. Mislabeled data discovered by UMAP

In the original UMAP mapping, there was an extra point labeled $\mathrm{H}$ that appeared in the ellipse for the $\mathrm{L}$ phenotype. This point, shown in red in Fig. S2a, later revealed itself as an error in the COVIDx dataset $^{3,6}$ : it was labeled as a frontal (PA) chest $\mathrm{x}$-ray in the physician notes, when in fact it is a lateral (side) $\mathrm{x}$-ray image (Fig. S2b). We removed this data point in subsequent analysis.

a

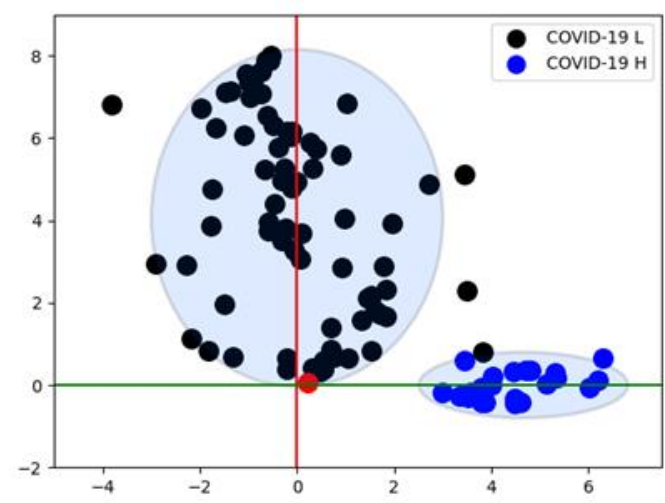

b

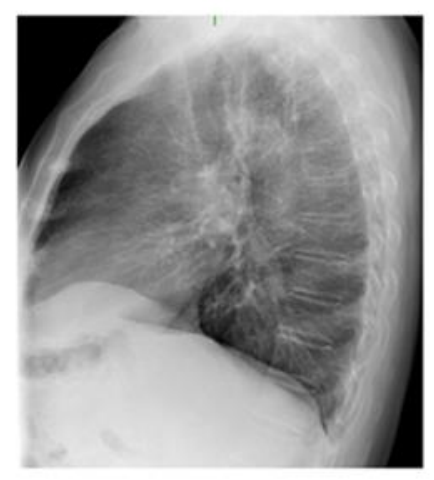

Figure S2. Discovery of mislabeled data. (a) Fig. 3a from main text with mislabeled data point added in red. (b) Chest $\mathrm{x}$-ray of mislabeled point, showing side view rather than frontal (PA) view.

\section{Examples and Outliers From UMAP}

We present some representative samples from the UMAP plot given in the main text (Fig. 3a). Shown are points within each cluster, at the boundaries, and in the outlying regions. Results for the L phenotype are given first, followed by those for the H phenotype. Under each $\mathrm{x}$-ray image, we also give the available radiologist and physician notes ${ }^{6}$.

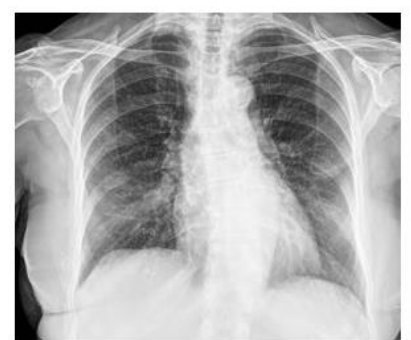

Admitted at A\&E with shortness of breath. There is a coarsening of lung markings more evident at the lower fields $(R>L)$ but no clear consolidation seen. Surgical clips overlie the right breast shadow.

Age: 70, Female, Location: Italy

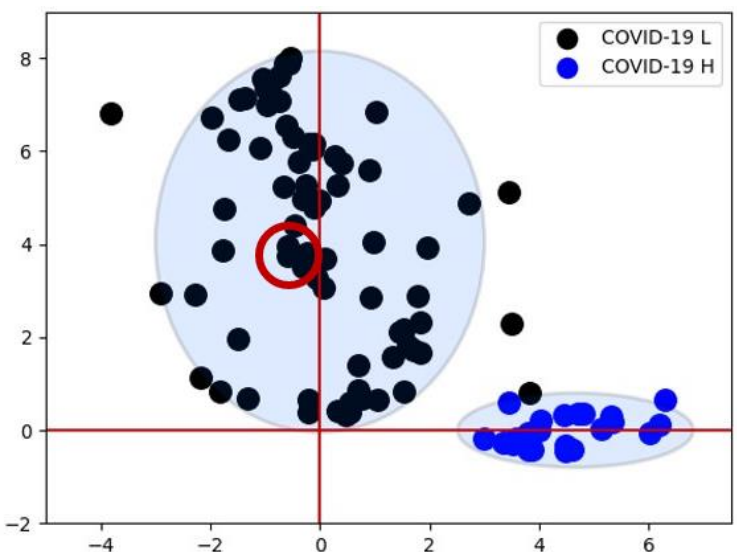

Figure S3. Typical $x$-ray image within the $L$ cluster. 
medRxiv preprint doi: https://doi.org/10.1101/2020.04.27.20081984; this version posted May 3, 2020. The copyright holder for this preprint (which was not certified by peer review) is the author/funder, who has granted medRxiv a license to display the preprint in perpetuity.

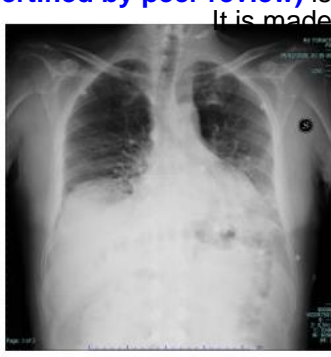

Hypo-expanded thorax with dysventilation of the lung bases and nuanced thickening of the lung fields, greater than left. Right paratracheal calcific lymph nodes. No signs of heart failure.

Age:65, Male, Stage of Illness: 32, Location: Italy

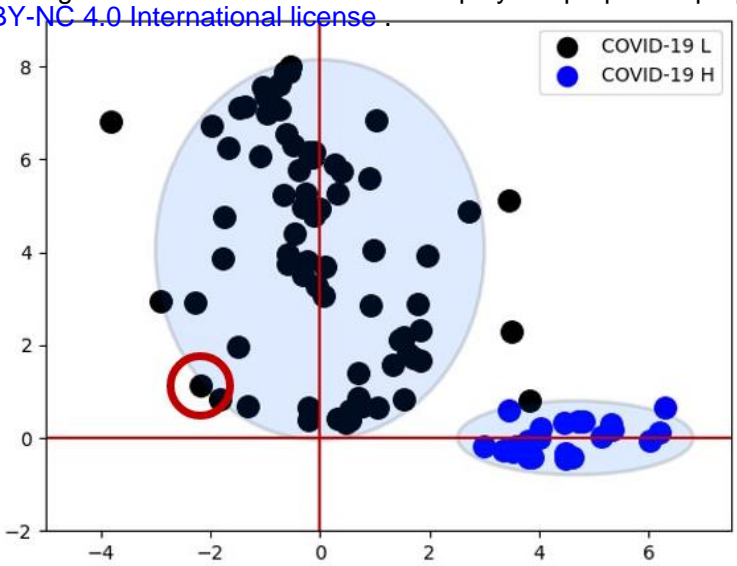

Figure S4. x-ray image at the boundary of the $L$ ellipse.

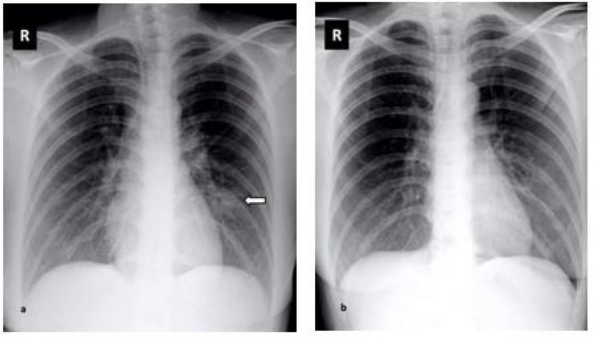

Initial chest radiograph (left) revealed a left infrahilar focal consolidation (arrow). Follow-up chest radiograph (right) performed 7 days later showed interval resolution. The patient was stable during admission, without need for oxygen supplementation.

Location: Singapore

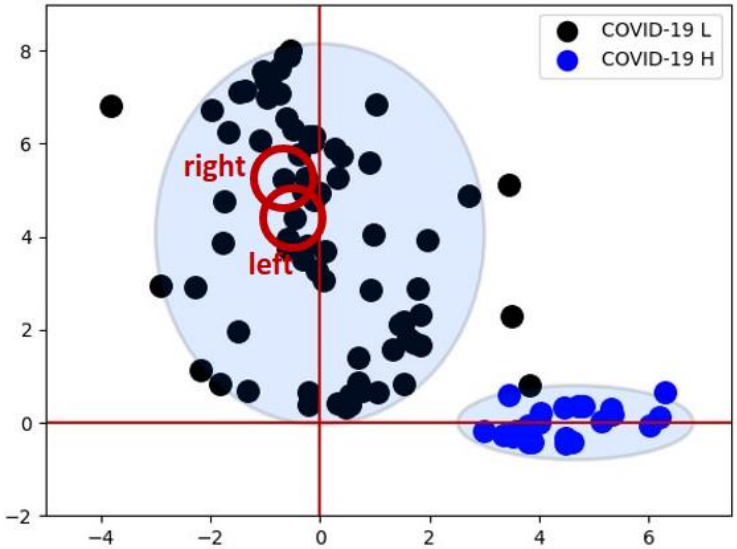

Figure S5. x-ray images of a stable patient in the $\mathbf{L}$ cluster.
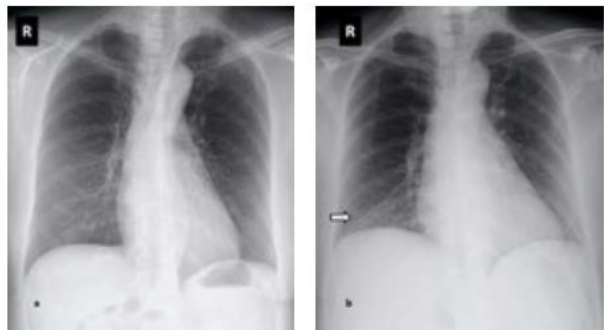

Serial chest radiographs of patient who presented with fever, cough and sore throat. Initial chest radiograph (left) was normal. chest radiograph (right) performed 10 days later showed interval development of a right lower zone ground-glass opacity. The patient was stable during admission, without requiring oxygen supplementation.

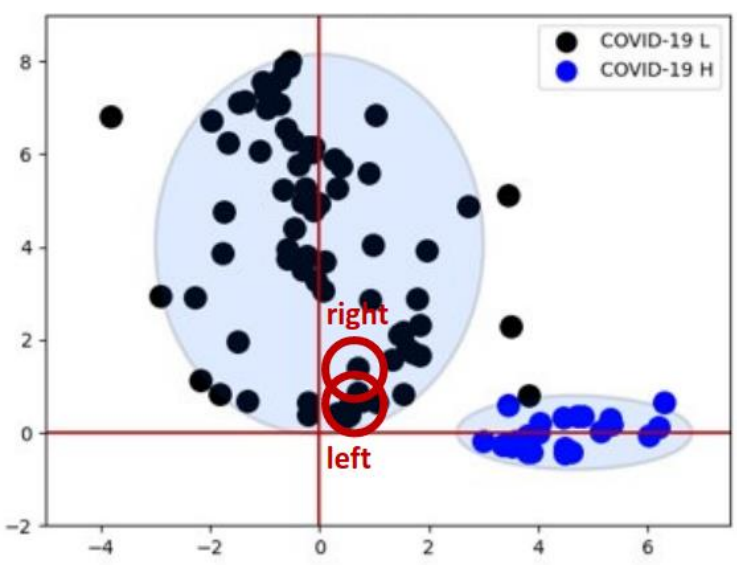

Figure S6. $x$-ray images of a stable patient in the $L$ cluster. 
medRxiv preprint doi: https://doi.org/10.1101/2020.04.27.20081984; this version posted May 3, 2020. The copyright holder for this preprint (which was not certified by peer review) is the author/funder, who has granted medRxiv a license to display the preprint in perpetuity.

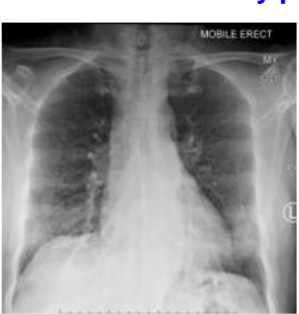

Day 5

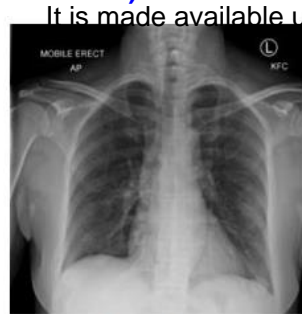

Day 10

Chest radiography demonstrated bi-basal infiltrates at day 5 that cleared on day 10 . No other respiratory pathogens were detected. Her management was intravenous fluid rehydration without supplemental oxygenation. No antibiotics, steroids or antiviral agents were administered.

Female, Location: Australia,

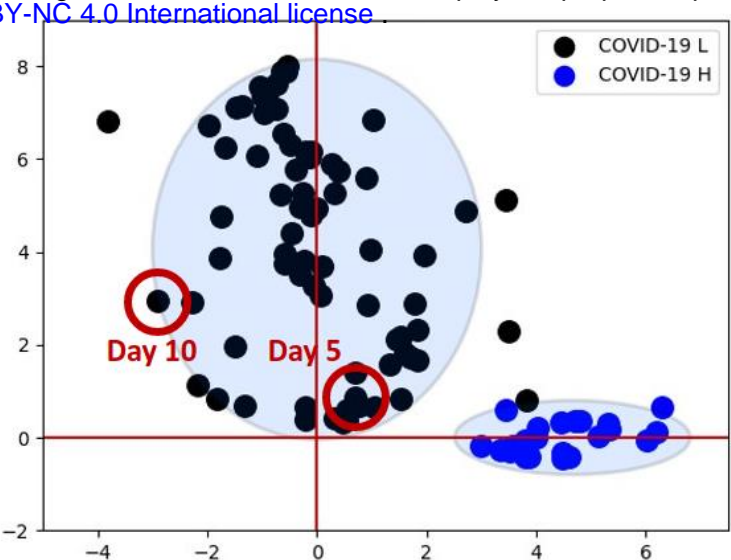

Figure S7. Progression of recovery in the $\mathbf{L}$ cluster. Points move from right to left in parameter space.
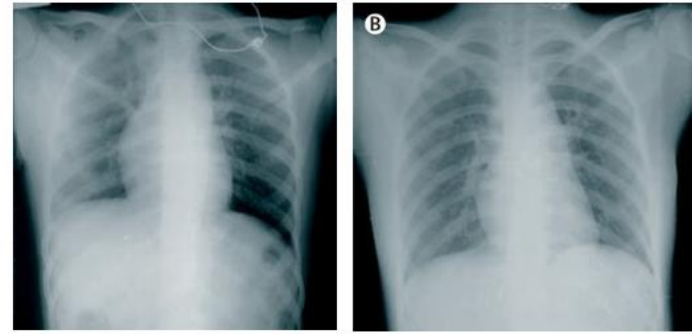

X-ray done at admission (January 24). Chest radiography showed no abnormalities. X-ray done 4 days after admission (January 28). The patient had a high fever, dry cough, and chest pain for the first 2 days. On day 3 , her fever subsided and her clinical condition began to improve.

Age: 25, Female, Stage of Illness: 7,11, Location: Vietnam

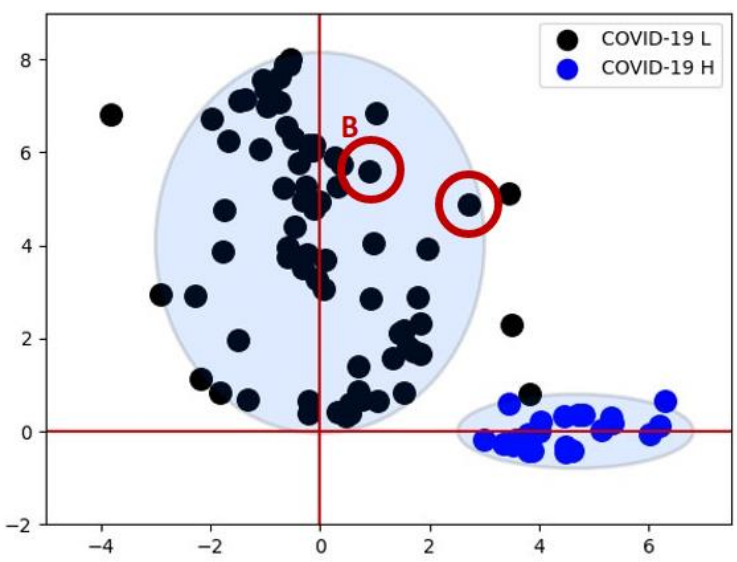

Figure S8. Progression of recovery in the $\mathbf{L}$ cluster. Points move from right to left in parameter space.
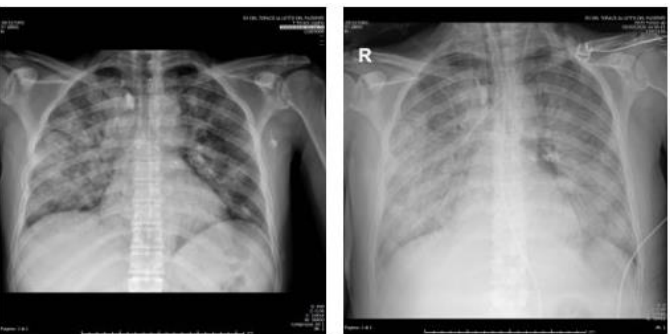

(Left) Upon entering hospitalization and in the light of the radiological finding, request for Covid 19 infectious disease assessment and research, which is positive. In the next hour worsening of dyspnea and need for hospitalization in resuscitation.

(Right) Chest $\mathrm{x}$-ray in patient in mechanical ventilation.

Age: 58 , Male, Stage of Illness: 7, Location: Italy

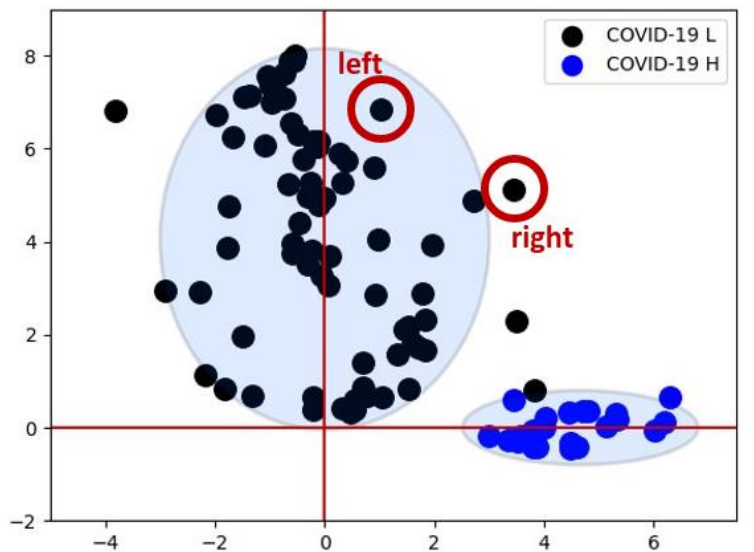

Figure S9. Progression of illness in the $\mathbf{L}$ cluster. Points move from left to right in parameter space. 
medRxiv preprint doi: https://doi.org/10.1101/2020.04.27.20081984; this version posted May 3, 2020. The copyright holder for this preprint (which was not certified by peer review) is the author/funder, who has granted medRxiv a license to display the preprint in perpetuity.

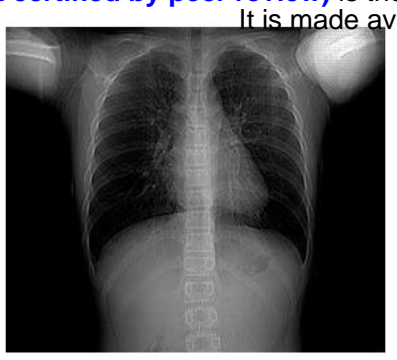

Chest x-ray images and chest CT images from a 12 -year-old boy showing that there was no abnormal density shadow in the parenchyma of both lungs, the structure of pulmonary hilus was clear, the trachea was unobstructed, mediastinum was not displaced, and no enlarged lymph node shadow was found.

Age:12, Male, Location: China

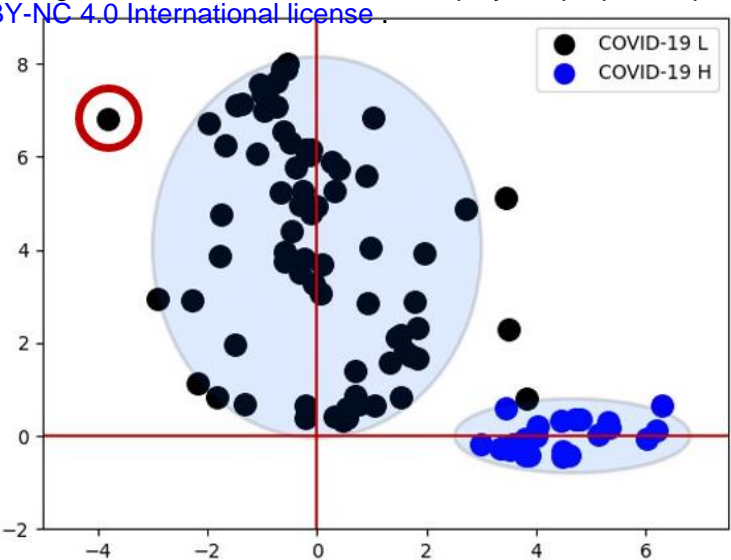

Figure S10. UMAP placement of the youngest COVID-19 patient in the COVIDx dataset.

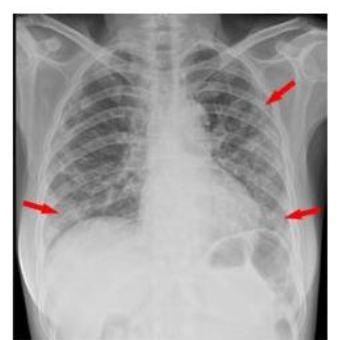

Chest radiography of confirmed Coronavirus Disease 2019 (COVID-19) pneumonia A 53-year-old female had fever and cough for 5 days. Multifocal patchy opacities can be seen in both lungs (arrows).

Female, Stage of Illness:5, Location: China

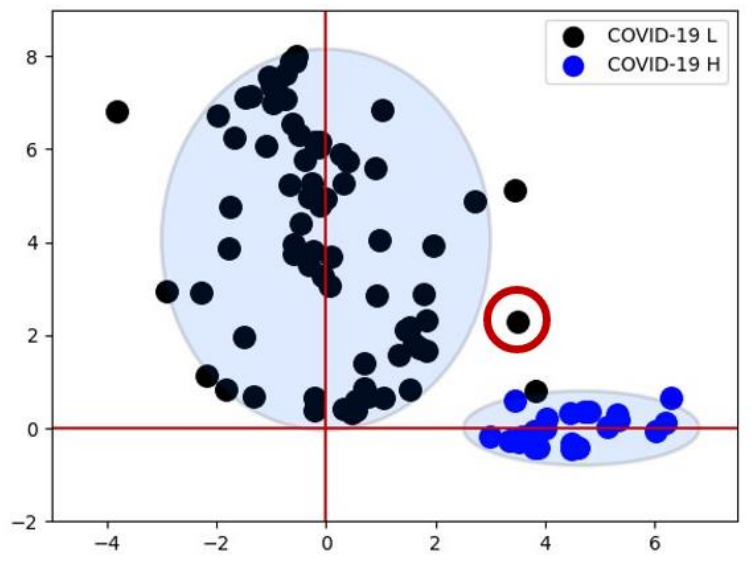

Figure S11: Outlier between the $L$ and $H$ ellipses.

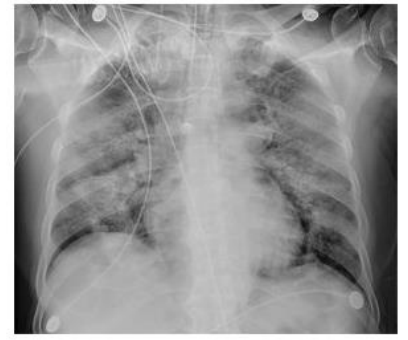

Diffusely increased opacities in both lungs, with relative bibasilar sparing.

Age: 71, Male, Stage of Illness: 6, Location: N/A

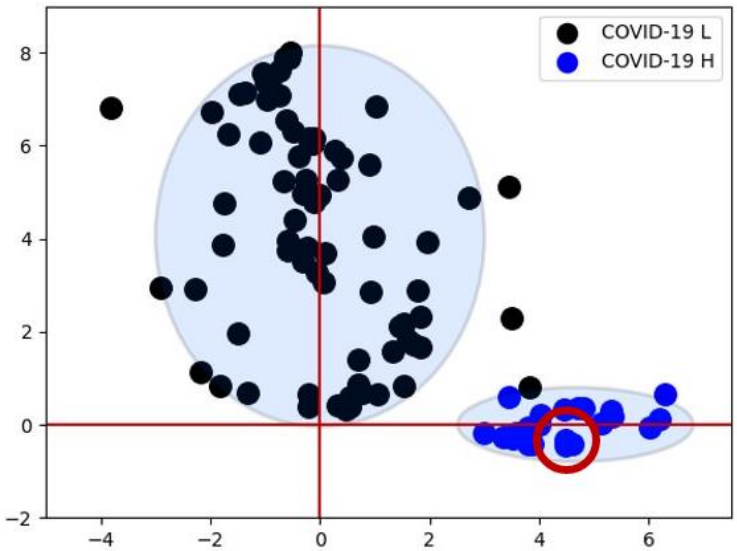

S12. Typical $x$-ray image within the $H$ cluster. 
medRxiv preprint doi: https://doi.org/10.1101/2020.04.27.20081984; this version posted May 3, 2020. The copyright holder for this preprint (which was not certified by peer review) is the author/funder, who has granted medRxiv a license to display the preprint in perpetuity.

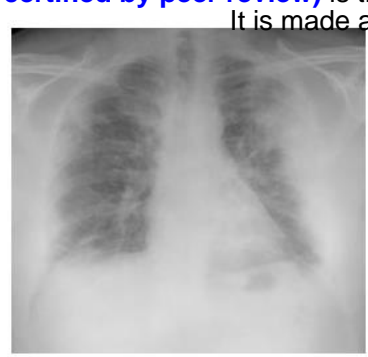

Attended the emergency department for progressive dyspnea in the last few days along with fever and cough. On the blood test, lymphopenia is detected. Bilateral and peripheral alveolar consolidations, more prominent in the left lung.

Age: 55, Male, Stage of Illness: 0, Location: Spain

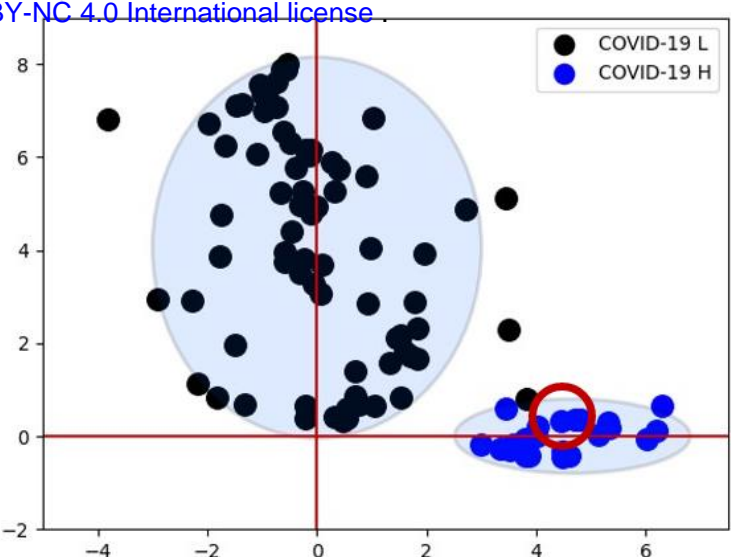

Figure S13: Typical $x$-ray image within the $H$ cluster.

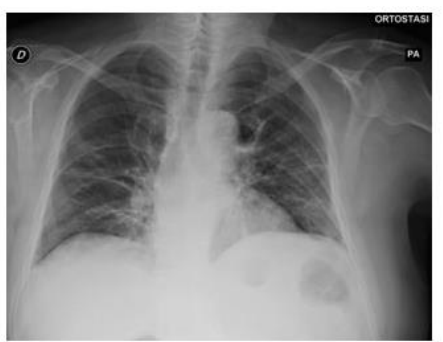

68-year-old man with chronic lymphatic leukemia in follow-up, high blood pressure and dyslipidemia. For 7 days, hyperpyrexia with dyspnoea and diarrheal alve has appeared. Leukocytosis, elevated PCR and normal procalcitonin. Multiple bilateral ribbon-like parenchymal thickenings. No pleural effusion.

Age: 68 , Male, Stage of Illness: 7, Location: Italy

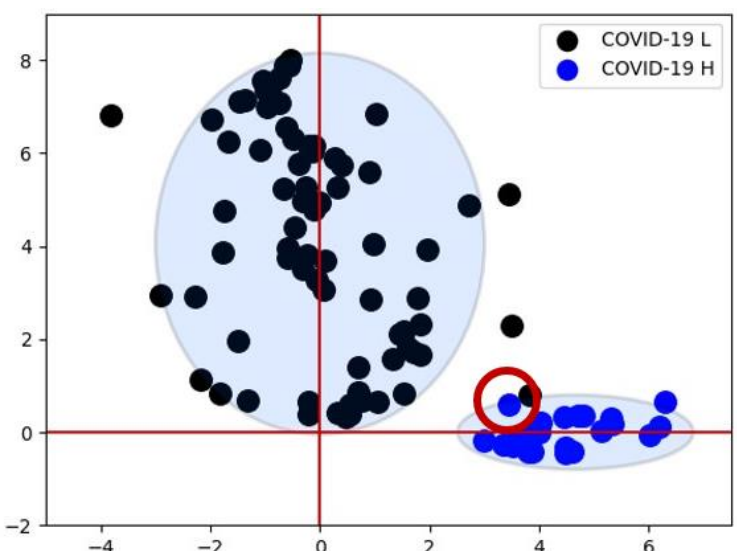

Figure S14: $\mathbf{x}$-ray image on the boundary of the $\mathbf{H}$ cluster. The patient has lymphatic leukemia, which would put him in the high-risk $\mathrm{H}$ category regardless of imaging. perihilar consolidation. Follow-up chest radiograph (right) performed
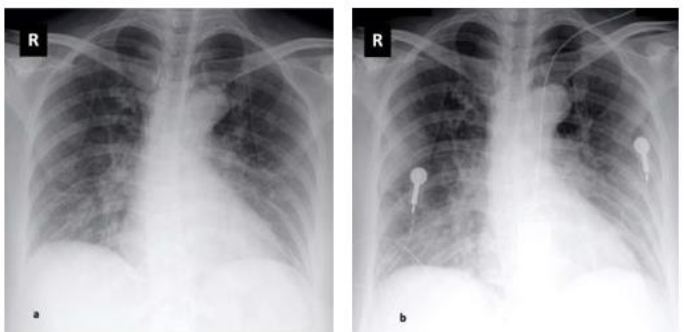

Serial chest radiographs of a patient who presented with fever and cough. Initial chest radiograph (left) showed bilateral predominant 5 days later showed interval worsening of bilateral perihilar and lower zone consolidation.

Stage of Illness: 5, Location: Singapore

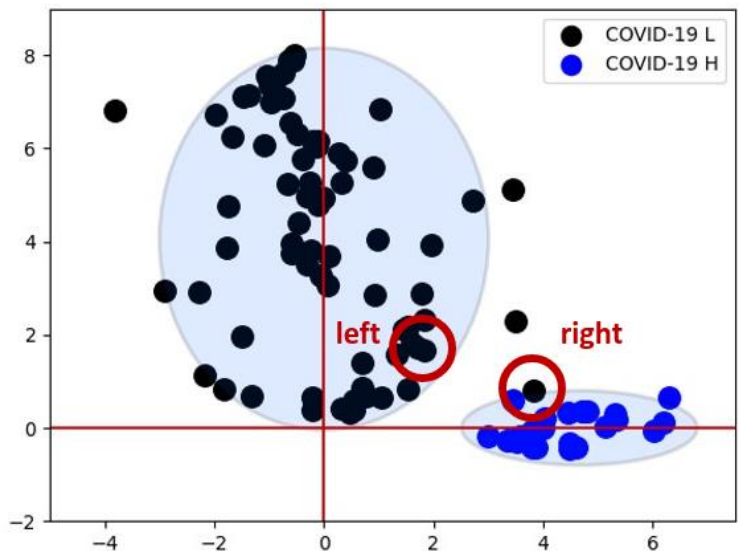

Figure S15: Mislabeled x-ray image in the $H$ cluster, near the point in Fig. S14. Label from t-SNE, placement from UMAP. As before, disease worsening progresses from left to right in parameter space. 
medRxiv preprint doi: https://doi.org/10.1101/2020.04.27.20081984; this version posted May 3, 2020. The copyright holder for this preprint (which was not certified by peer review) is the author/funder, who has granted medRxiv a license to display the preprint in perpetuity.

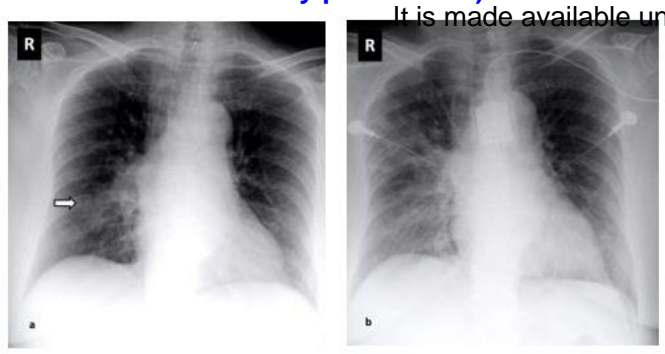

Initial chest radiograph (left) showed a right infrahilar focal consolidation (arrow). A follow-up radiograph (right) performed 7 days later demonstrated worsening right lung changes with predominant perihilar mixed GGO and consolidation.

Stage of Illness: 7, Location: Singapore

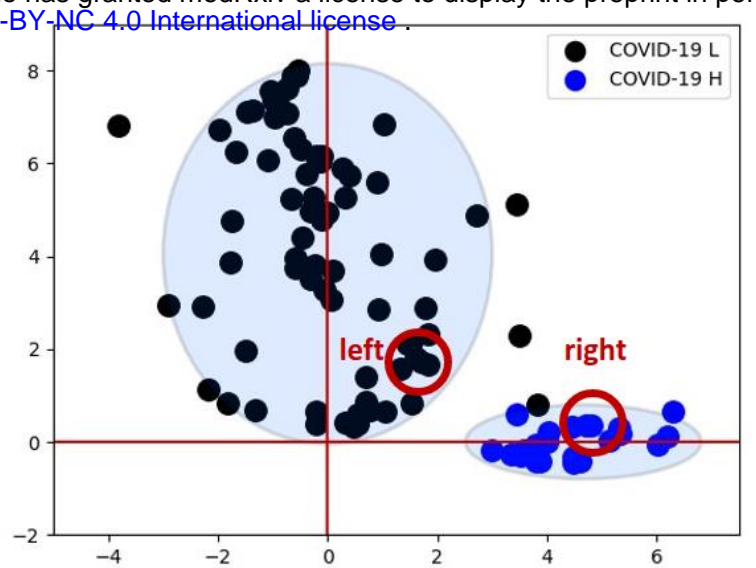

Figure S16: Disease progression from $L$ cluster to $H$ cluster.
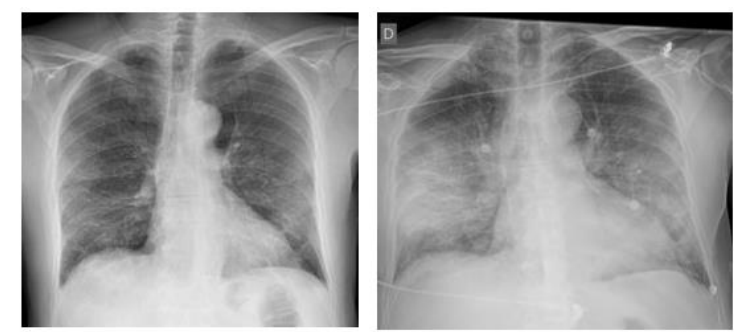

(Left) No significant findings reported. In retrospect, a subtle groundglass pattern can be seen in both lungs, with peripheral distribution. (right) 2 Days Later. Bilateral ground-glass alveolar consolidation with peripheral distribution.

Age 70, Male, Stage of Illness: 0, 2, Location: Spain

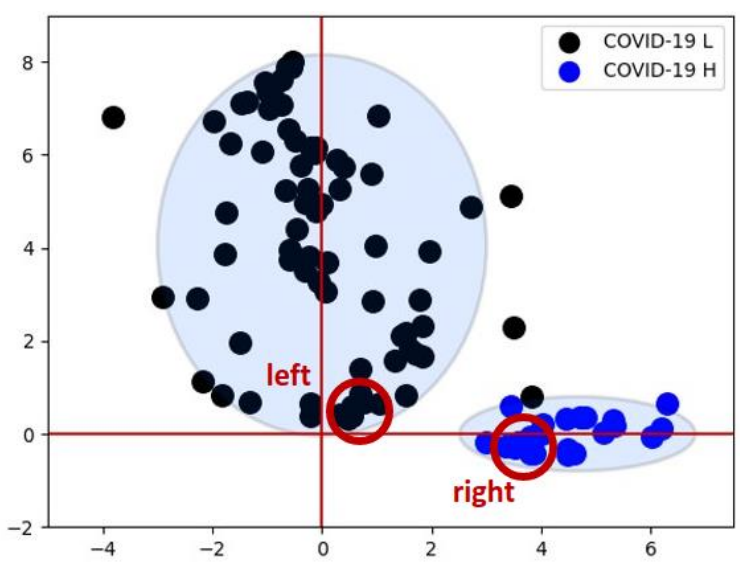

Figure S17: Disease progression from $\mathbf{L}$ cluster to $\mathbf{H}$ cluster.

\section{Predictive testing of UMAP}

Covid-19 $\mathrm{x}$-ray data is very limited and does not allow for significant predictive testing of the network. Nevertheless, we saved a small number of $\mathrm{x}$-rays from the COVIDx dataset ${ }^{6}$ to analyze performance on new patients, viz. 100 normal x-ray images, 100 pneumonia x-ray images, and 10 COVID-19 x-ray images. Results are shown in Figs. S18-22. As seen in previous applications of UMAP for phenotyping ${ }^{7}$, the new data points appear on the periphery of the previously learned mapping. As before, some patients have multiple chest x-rays, allowing comparison of different stages of illness. 
medRxiv preprint doi: https://doi.org/10.1101/2020.04.27.20081984; this version posted May 3, 2020. The copyright holder for this preprint (which was not certified by peer review) is the author/funder, who has granted medRxiv a license to display the preprint in perpetuity.
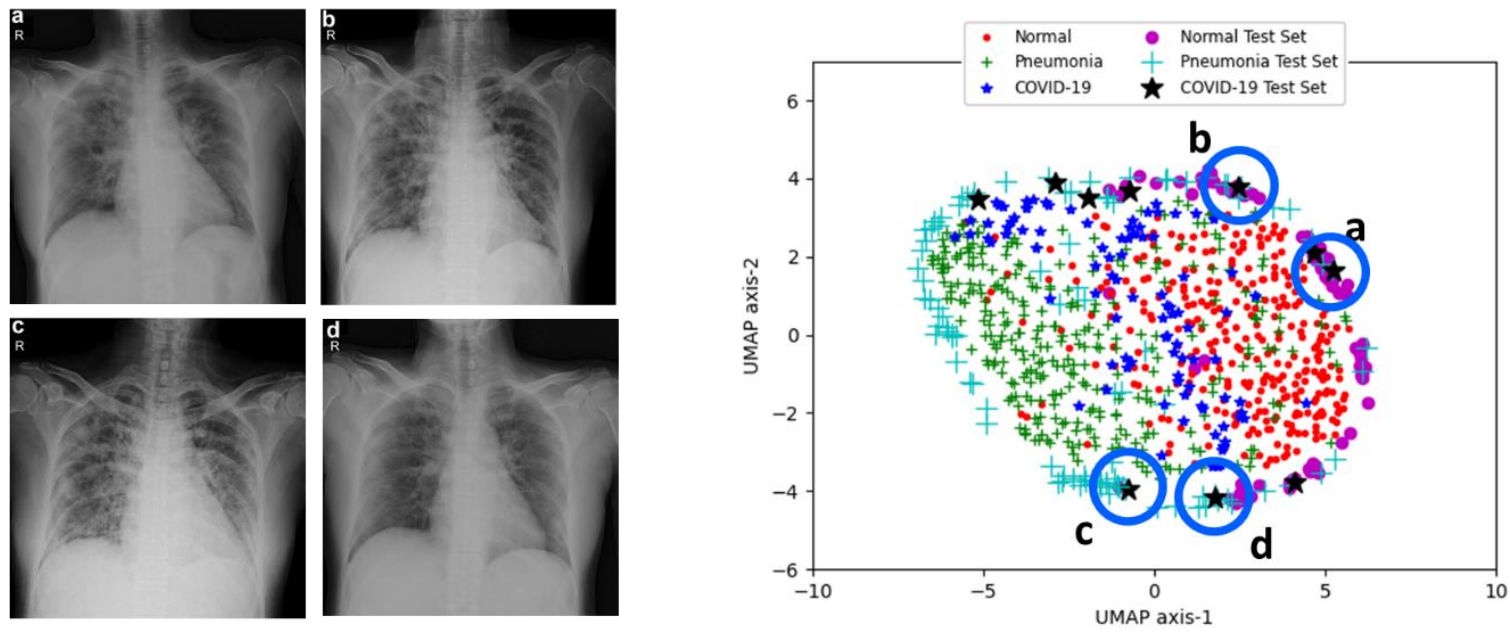

Our case demonstrated a typical NCP without progression to ARDS. Chest X-ray showed progression of prominent bilateral perihilar infiltration and ill-defined patchy opacities at bilateral lungs, which slowly resolved on the follow-up image.

Location = Taiwan, Age: 55, Female,

Stage of Illness: $10,13,17,25$

Figure S18. Progression of illness and recovery for L-type patient. Shown are x-rays from the same patient taken at (a) 10, (b) 13, (c) 17, and (d) 25 days after onset of illness ${ }^{8}$. Note that (c) corresponds to the worst stage of the disease and maps to the pneumonia-like cluster. $(a, b)$ Worsening of disease. (c,d) Patient improvement.
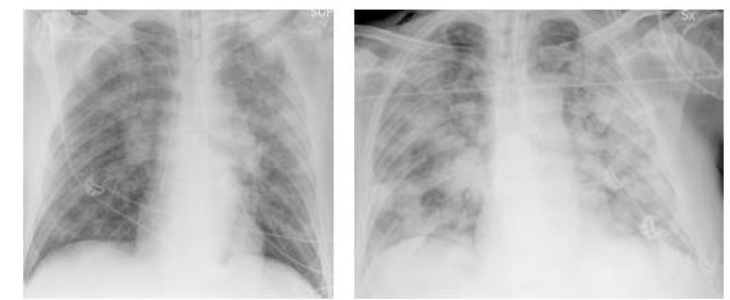

(left) 60 year old man, Dyspnea and fever onset, APR: silent. Bilateral "ground glass" parenchymal thickenings with a phlogistic

(right) the appearance, on both sides, also in correspondence of the middle-lower fields, of multiple parenchymal thickening tending to the confluence, possible expression of bronchopneumonic foci.

Age: 60 , Male, Stage of Illness: 5, 15, Location: Italy aspect on both upper lobes.

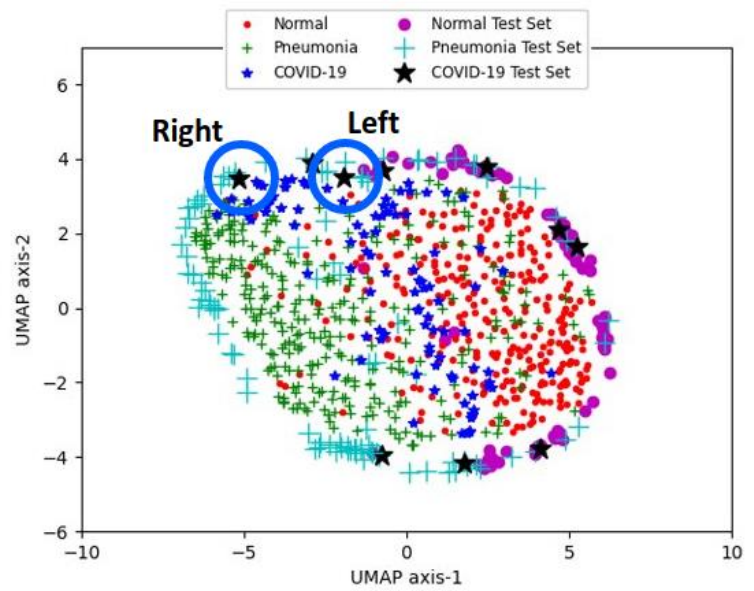

Figure S19. Progression of illness for H-type patient. As before, the x-ray becomes more pneumonialike as the condition worsens. 
medRxiv preprint doi: https://doi.org/10.1101/2020.04.27.20081984; this version posted May 3, 2020. The copyright holder for this preprint (which was not certified by peer review) is the author/funder, who has granted medRxiv a license to display the preprint in perpetuity. It is made available under a CC-BY-NC 4.0 International license.

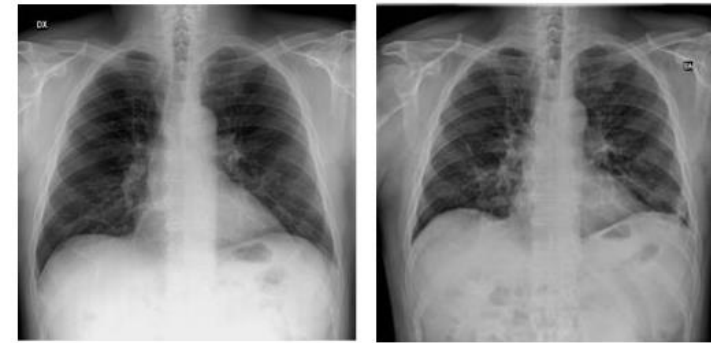

(left) Chest radiogram at onset, performed on an outpatient basis in another hospital: "No pleuroparenchymal thickenings; thickening of the peribronco-vascular interstitium."

(right) Multiple bilateral parenchymal thickenings in the lower lobes. Increase in interstitial thickening.

Age: 67, Male, Stage of Illness: 7, 13, Location: Italy,

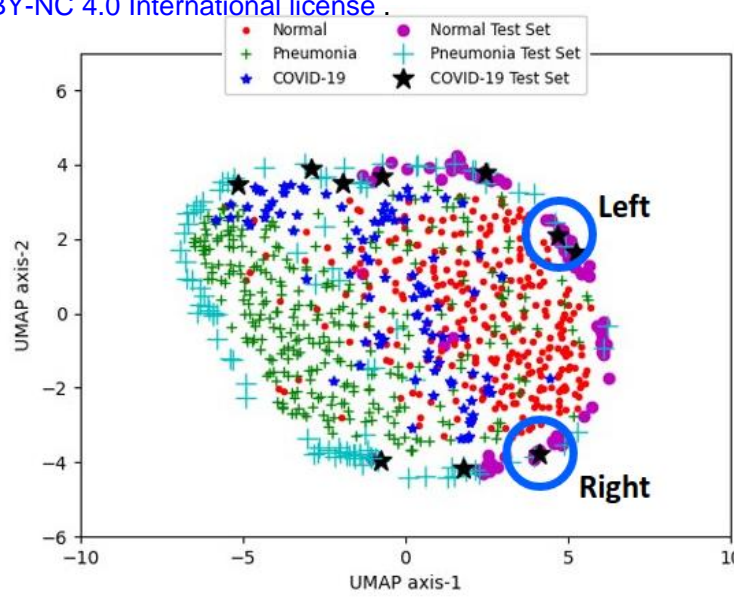

Figure S20. Slow progression of L-type patient.

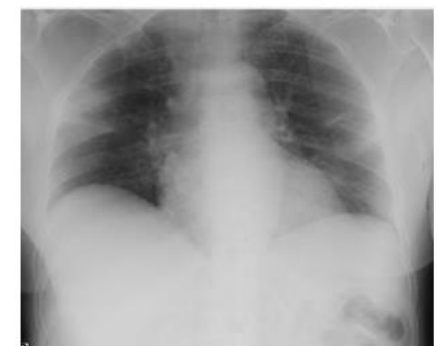

Women, 69 years old, has reported fever since one week treated with antibiotics without benefit. In the anamnesis, he does not report any noteworthy pathologies. PS temperature in the normal range $\left(36.5^{\circ}\right)$, p02 96\%, eupneic. The radiographic investigation shows a discrete increase in the peribronchovascular interstitium with associated some nuanced parenchymal thickenings at the base of both lungs. Cardiomediastinal shadow in the norm. Normo-expanded costophrenic sinuses.

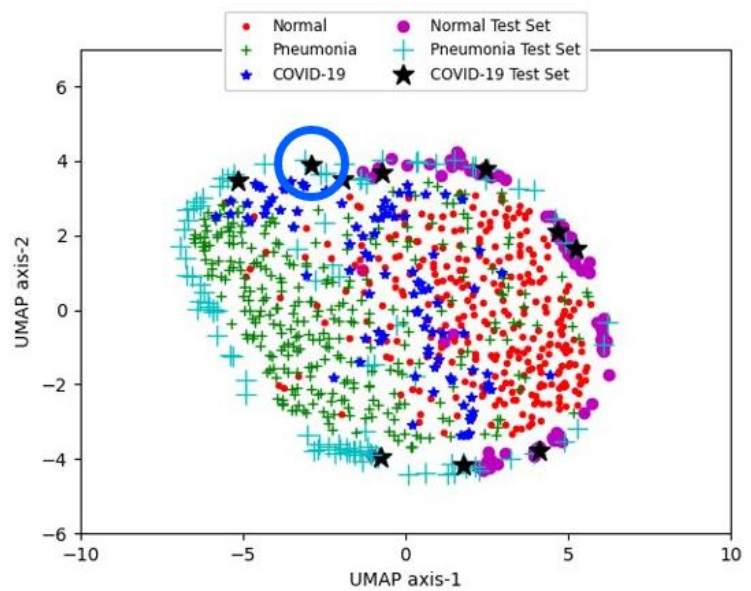

Age: 59, Female, Stage of IIIness: 7, Location: Italy

Figure S21. New x-ray image placed near origin of L-H axes.

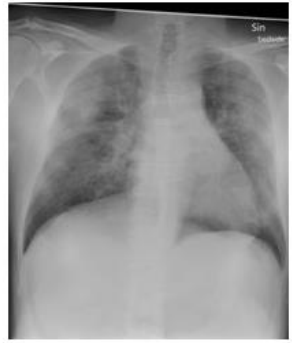

Elderly male, covid-19 positive. Fever and elevated c-reactive protein. Perihilar and apical, mostly peripheral, opacifications bilaterally. COVID-19 radiographic appearances are similar to those of other respiratory infections.

Male, Location: Sweden

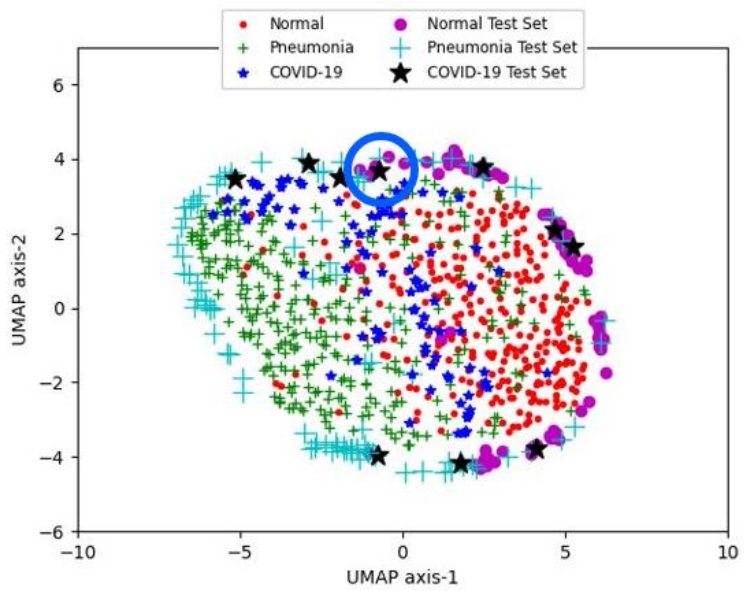

Figure S22. New x-ray image placed near origin of L-H axes. 


\section{REFERENCES} It is made available under a CC-BY-NC 4.0 International license.

1 van der Maaten, L. \& Hinton, G. Visualizing data using t-SNE. Journal of Machine Learning Research 9, 2579-2605 (2008).

2 McInnes, L. \& Healy, J. UMAP: Uniform Manifold Approximation and Projection for Dimension Reduction. (2018).

3 Wang, L. \& Wong, A. COVID-Net: A Tailored Deep Convolutional Neural Network Design for Detection of COVID-19 Cases from Chest Radiography Images. arXiv 2003:09871 (2020).

4 Wattenberg, M., Viegas, F. \& Johnson, I. How to use t-SNE effectively, https://distill.pub/2016/misread-tsne/ (2016).

5 Laurens van der, M. 384-391 (PMLR, 2009).

6 Cohen, J. P., Morrison, P. \& Dao, L. Covid-19 Image Data Collection. arxiv 2003.11597 (2020).

7 Hurley, N. C., Haimovich, A. D., Taylor, R. A. \& Mortazavi, B. J. Visualization of Emergency Department Clinical Data for Interpretable Patient Phenotyping. CoRR abs/1907.11039 (2019).

8 Cheng, S.-C. et al. First case of Coronavirus Disease 2019 (COVID-19) pneumonia in Taiwan. Journal of the Formosan Medical Association 119, 747-751 (2020). 